\title{
Effect of fish meal replacement by plant protein sources on non-specific defence mechanisms and oxidative stress in gilthead sea bream (Sparus aurata)
}

\author{
A. Sitjà-Bobadilla ${ }^{a}{ }^{*}$, S. Peña-Llopis ${ }^{a}$, P. Gómez-Requeni ${ }^{a}$, F. Médale ${ }^{b}$, \\ S. Kaushik ${ }^{b}$, J. Pérez-Sánchez ${ }^{a}$

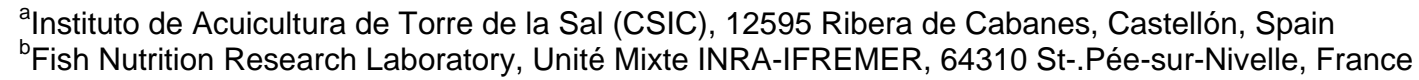

*: Corresponding author : A. Sitjà-Bobadilla, email address : ariadna@iats.csic.es

\begin{abstract}
:
Partial or total replacement of fish meal by a mixture of plant protein (PP) sources (corn gluten, wheat gluten, extruded peas, rapeseed meal and sweet white lupin) balanced with indispensable amino acids was examined in juvenile gilthead sea bream over the course of a 6-month growth trial. A diet with fish meal (FM) as the sole protein source was compared to diets with $50 \%, 75 \%$ and $100 \%$ of replacement (PP50, PP75, and PP100). The possible influence of diets on growth performance, plasma metabolites, gut integrity, liver structure, anti-oxidant and immune status was evaluated. Final body weight was progressively decreased with PP inclusion, but in PP50 and PP75-fed fish, feed efficiency (FE) was significantly improved and specific growth rates remained unchanged or slightly reduced in comparison to fish fed the FM diet. In fish fed PP100 diet, FE remained unchanged and feed intake and growth decreased dramatically. In this group of fish, liver fat deposition was also largely increased, enterocytes showed an increased number of lipidic vacuoles and/or deposition of protein droplets, and the submucosa of intestine was dilated/hypertrophied and infiltrated with eosinophilic granular cells. Plasma glucose levels did not differ among the four groups, but a significant and progressive decrease of plasma cholesterol and plasma protein levels was found with FM replacement. The glutathione redox status in blood and liver increased with the increase of PP content and this increment was statistically significant in the liver of the three PP-fed groups. Glutathione reductase and y-glutamyl transferase were also enhanced by PP inclusion. Plasma lysozyme levels were not altered by the dietary treatment, but respiratory burst of head kidney leucocytes and plasma myeloperoxidase values were significantly increased in PP75 and PP100 fish, respectively. Complement (ACH50) was significantly increased in PP50 fed fish and decreased in PP75 and PP100 groups. As a general conclusion, substitution of FM by a mixture of PP sources exerted an anti-oxidative effect, compromised growth performance only at the $100 \%$ level, and decreased one of the immune defence mechanisms at above $75 \%$ level.
\end{abstract}

Keywords: Fish meal; Plant proteins; Growth; Immune response; Respiratory burst; Lysozyme; Complement; Myeloperoxidase; Histopathology; Glutathione; Cholesterol; Gilthead sea bream. 


\section{Introduction}

In the last decade the increasing demand, price and world supply fluctuations of fish meal (FM) has emphasized the need to look for alternative protein sources in aquafeeds. Much attention has been focused on plant proteins (PP), although their use is limited by deficiencies in essential amino acids and minerals, and the presence of antinutrititional factors (ANFs) and complex carbohydrates (NRC, 1993; Vielma et al., 2003). Certain constituents of plants (mainly soybean) have also been shown to have immunological activity, to act as antigens, or to produce histopathological damage in the digestive tract (Rumsey et al., 1994; Baeverfjord and Krogdahl, 1996; Krogdhal et al., 2003). In addition, several plants contain phenolic compounds with potent antioxidant activities, which have been associated with beneficial health effects in humans (Adom and Liu, 2002), and the glutathione redox status, considered an index of the cellular redox status and a biomarker of oxidative damage, has been used to assess their antioxidant activity.

Previous studies in gilthead sea bream (Sparus aurata) have shown that partial replacement of FM by PP is possible (Robaina et al., 1995; Kissil et al., 2000; Pereira and Oliva-Teles, 2002, 2003). In a short-term trial (3 months), we also explored the possibility of total and graded replacement of FM by a mixture of PP supplemented with indispensable amino acids (GómezRequeni et al., 2004). In this first approach, growth performance, amino acid utilisation and somatotropic axis responsiveness were analysed. In the current study, the effect of feeding with FM replaced diets was evaluated at a longer term not only on the basis of growth performance, but also on terms of gut integrity, liver structure, and anti-oxidant and immune status.

\section{Materials and Methods}

\subsection{Diets, experimental design and sampling}

Juvenile gilthead sea bream were obtained from a South Atlantic fish farm (CUPIMAR, Cádiz, Spain). Fish were acclimated to laboratory conditions for 20 days before being randomly distributed into fibreglass tanks of 500-I capacity. Fish of $\quad 16-17 \mathrm{~g}$ initial body weight were distributed into 12 experimental tanks (500-I) in triplicate groups of 90 fish each. Water flow was $20 \mathrm{l} / \mathrm{min}$, and oxygen content of outlet water remained higher than $85 \%$ saturation. Day length and temperature increased over the course of the trial (April - Sept 2002), following natural changes at our latitude $\left(40^{\circ} 5^{\prime} \mathrm{N} ; 0^{\circ} 10^{\prime} \mathrm{E}\right)$. Sea water temperature ranged from 17 to $25^{\circ} \mathrm{C}$ and water salinity was $37.5 \%$.

A growth trial was designed using four different diets. They were isonitrogenous and based on FM as the only protein source or a mixture of PP sources (corn gluten, wheat gluten, extruded peas, rapeseed meal and sweet white lupin), which were formulated to replace the 50 (PP50), 75 (PP75) and $100 \%$ (PP100) of FM protein. Crystalline amino acids were added to PP-based diets to achieve an equivalent indispensable amino acid profile (Table 1). For more details on diet composition, see Gómez-Requeni et al. (2004).

During the growth trial (6 months), each diet was randomly allocated to triplicate tanks of fish. Feed was offered by hand to apparent visual satiety in two meals per day (0900 h, $1400 \mathrm{~h}$ ), and feed consumption was recorded daily. At the end of the growth trial, blood and tissue sampling was done from randomly selected fish. Following overnight fasting, animals were anaesthetised (3-aminobenzoic acid ethyl ester, MS 222; $100 \mu \mathrm{g} / \mathrm{ml}$, Sigma) to obtain blood from caudal vessels. Some blood samples ( $n=7 /$ diet) were used directly for the measurement of oxidative stress metabolites, and others ( $n=10 /$ diet) to obtain plasma after centrifugation at $3000 \mathrm{~g}$ for 20 min at $4^{\circ} \mathrm{C}$. They were stored at $-30^{\circ} \mathrm{C}$ and $-80^{\circ} \mathrm{C}$ until metabolite and immunological analyses were performed, respectively. After killing the fish by a blow to the head, samples of liver and dorsal portions of muscle ( $n=7 / \mathrm{diet}$ ) were excised and frozen in liquid nitrogen, and stored at $80^{\circ} \mathrm{C}$ prior to analyses. Liver and distal intestine $(n=7 /$ diet $)$ were also taken for histological processing. Finally, four fish from each group were sampled for the assessment of respiratory burst activity and the myeloperoxidase (MPO) content in head kidney leucocytes. The experimental procedure complies with the current laws of Spain. 


\subsection{Oxidative stress and metabolite assays}

\subsubsection{Glutathione determinations}

Blood samples were immediately deproteinised by adding 5 volumes of ice-cold $5 \% 5$ sulfosalicylic acid to avoid auto-oxidation of reduced gluthathione (GSH) and/or cleavage of glutathione by $\gamma$-glutamyl transferase $(\gamma \mathrm{GT}$ ) (Anderson, 1985). After centrifugation for $10 \mathrm{~min}$ at $20,000 \mathrm{~g}$ and $4^{\circ} \mathrm{C}$, glutathione levels were determined in the clear supernatants. Frozen liver and muscle samples were homogenised with 5 volumes of ice-cold 5-sulfosalicylic acid, and further processed by sonication (Vibra-Cell, Sonics \& Materials Inc., Danbury, CT, USA). Homogenates were then centrifuged as above.

For both types of samples, total glutathione content (tGSx) and oxidised glutathione (GSSG) were determined with a sensitive assay based on the recycling reaction of GSH with 5,5'dithiobis (2-nitrobenzoic acid) (DTNB) in the presence of an excess of glutathione reductase (GR) according to Baker et al. (1990). Measurements were made in a microplate reader as previously described (Peña-Llopis et al., 2001). Reduced and oxidised glutathione ratios were calculated as follows:

$\mathrm{GSH} / \mathrm{GSSG}=(\mathrm{tGSx}-\mathrm{GSSG}) /(\mathrm{GSSG} / 2)$.

Glutathione-protein mixed disulfides (GSSP) in muscle and liver were measured according to the method of Rossi et al. (1995). GSSP levels were expressed as nmol of GSx per mg of protein.

\subsubsection{Enzyme kinetic assays}

Liver and muscle tissues were homogenised with 5 or 4 volumes of Henriksson stabilising medium as described elsewhere (Peña-Llopis et al., 2003a). Homogenates were centrifuged at $20,000 \mathrm{~g}$ for 20 minutes at $4{ }^{\circ} \mathrm{C}$. The resulting supernatants were diluted with buffer and assayed rapidly for enzyme activities.

GR (EC 1.6.4.2) activity was monitored by measuring the increase of absorbance values (415 $\mathrm{nm}$ ) with a reference wavelength of $595 \mathrm{~nm}$ (Cribb et al., 1989). The final concentrations of $0.075 \mathrm{mM}$ DTNB, $0.1 \mathrm{mM} \mathrm{NADPH}$, and $1 \mathrm{mM}$ GSSG were used according to Smith et al. (1988). $\gamma$ GT (EC 2.3.2.2) activity was determined by the method of Silber et al. (1986). The rate of the substrate analogue $\gamma$-glutamyl- $p$-nitroanilide cleavage to form $p$-nitroaniline (pNA) by transfer of a glutamyl moiety to glycylglycine was monitored at $405 \mathrm{~nm}$ for at least ten min.

A calibration curve of known activities of purified enzymes was used on every 96-well plate. GR (type III) from baker's yeast and $\gamma \mathrm{GT}$ (type I) from bovine kidney were used as standards, whose activities were determined in quartz cuvettes using a Hitachi U-2001 UV/Vis spectrophotometer (Hitachi Instruments Inc., USA). A molar absorption coefficient at $412 \mathrm{~nm}$ of 14.150 was used for the dianion of DTNB $\left(\mathrm{TNB}^{2-}\right)$ as per Riddles et al. (1979). Specific enzyme activities were expressed as nmoles of substrate hydrolysed per min and per $\mathrm{mg}$ of protein ( $\mathrm{mU} / \mathrm{mg}$ prot).

\subsubsection{Protein determination and plasma metabolite assays}

Protein content of plasma and tissue homogenates was determined by the Bio-Rad Protein Assay kit (Bio-Rad Laboratories $\mathrm{GmbH}$, Munich, Germany) based on the Bradford dye-binding procedure, using bovine serum albumin as standard.

Plasma glucose, triglycerides and cholesterol were determined spectrophotometrically using commercial kits Sigma 315-100, Sigma 337-B and Sigma 401-25P, respectively.

\subsubsection{Histology}

The occurrence of possible histopathological damages was studied in liver and posterior gut. Tissue portions taken from a given part of the organ were fixed in $10 \%$ buffered formalin, 
embedded in Technovit-7100 resin (Kulzer, Heraeus, Germany), and stained with toluidine blue (TB) or hematoxylin \& eosin (H \& E) after thin sectioning (1-3 $\mu \mathrm{m})$.

\subsection{Immunological assays}

\subsubsection{Plasma lysozyme}

Plasma lysozyme activity was measured by a turbimetric assay (Ellis, 1990) adapted to 96-well microplates. Briefly, lyophilized Micrococcus lysodeikticus $(0.3 \mathrm{mg} / \mathrm{ml}$ ) (Sigma) in $0.05 \mathrm{M}$ sodium phosphate buffer at $\mathrm{pH} 6.2$ was used as a substrate for the plasma lysozyme. Triplicates of test plasma (diluted 1:2, $10 \mu \mathrm{l}$ ) were added to $200 \mu \mathrm{l}$ of the bacterial suspension, and the reduction in absorbance at $450 \mathrm{~nm}$ was measured after 0.5 and $4.5 \mathrm{~min}$. A unit of lysozyme activity was defined as the amount of enzyme that caused a decrease in absorbance of 0.001 per min.

\subsubsection{Plasma complement}

The lysis by the alternative complement pathway (ACP) was determined as in Sitjà-Bobadilla et al. (2003), with some modifications. Briefly, sheep red blood cells (SRBC) obtained from sheep defibrinated blood (Biomedics, Spain) were used as targets at a final concentration of $2.5 \times 10^{8}$ cells $/ \mathrm{ml}$. Triplicates of tested plasma $(100 \mu \mathrm{l})$ diluted in HBSS-EGTA (Hank's Balanced Salt Solution, plus $10 \mathrm{mM} \mathrm{M}{ }^{2+}$ and $10 \mathrm{mM}$ ethylene glycolbistetra-acetate (EGTA), pH 7.6) were mixed with $25 \mu \mathrm{l}$ of SRBC in 96-well plates. Plates were incubated for $100 \mathrm{~min}$ at $20^{\circ} \mathrm{C}$ with constant shaking and then centrifuged to spin down the remaining SRBC. The absorbance of the supernatant was read at $415 \mathrm{~nm}$. The value $Y$ (percentage of SRBC lysed at each dilution) was defined as in Sunyer and Tort (1995). The plasma dilution factor, $X$, was plotted in logarithmic form against $Y$, using the Von Krogh equation as $\log X$ versus $\log Y I(1-Y)$. The dilution corresponding to $50 \%$ haemolysis/ml was expressed as $\mathrm{ACH}_{50}$.

\subsubsection{Myeloperoxidase (MPO) content}

Total MPO content in plasma and head kidney leucocytes was measured following the procedure described by Quade and Roth (1997) adapted to gilthead sea bream by Cuesta et al. (2002), with some modifications. Fifteen $\mu$ l of plasma were mixed with $135 \mu \mathrm{l}$ of HBSS-plus (pH 7.2. HBSS without $\mathrm{Ca}^{2+}$ and $\mathrm{Mg}^{2+}$ with $0.1 \% \mathrm{NaCl}$ and an antimycotic/antibiotic mixture (100 $\mathrm{U} / \mathrm{ml}$ penicillin, $100 \mu \mathrm{g} / \mathrm{ml}$ streptomycin, $0.25 \mu \mathrm{g} / \mathrm{ml}$ amphotericin B) in flat-bottomed 96 well plates (Nunc), and $50 \mu \mathrm{l}$ of 3,3',5,5'-tetramethylbenzidine hydrochloride (TMB, BioRad) were added. After 2 min of incubation, the reaction was stopped with $25 \mu \mathrm{l}$ of $1 \mathrm{~N} \mathrm{H}_{2} \mathrm{SO}_{4}$, and the optical density was read at $450 \mathrm{~nm}$. Wells in which no plasma was added were run as blanks. Three replicate wells were run for each fish.

Head kidney leucocyte suspensions were initially obtained as in Calduch-Giner et al. (1997) with some modifications. Briefly, after the second sedimentation, the pellet which was enriched in granulocytes (mainly eosinophiles) was adjusted to $20 \times 10^{6}$ cells $/ \mathrm{ml}$ in HBSS-plus. The MPO content was determined after incubation of the leucocyte suspension $(25 \mu \mathrm{l})$ with $125 \mu \mathrm{l}$ of the detergent cetyltrimethylammonium bromide (CTAB) (0.02\% in water). After 15 min of incubation at $22^{\circ} \mathrm{C}$ with constant shaking, TMB (diluted 1:4) and $1 \mathrm{~N} \mathrm{H}_{2} \mathrm{SO}_{4}$ were added as above. After centrifugation of the plates ( $400 \mathrm{~g}$ for $10 \mathrm{~min}$ ), $150 \mu \mathrm{l}$ of supernatants were transferred to new 96 well plates and read as above. The blank was obtained from wells to which no cells were added. Appropriate controls were included to monitor the degree of spontaneous degranulation of leucocytes. Three replicate wells were run for each fish.

\subsubsection{Respiratory burst activity}

Enriched leucocyte preparations from head kidney were obtained using the procedure described by Muñoz et al. (1998). Cells were adjusted to $20 \times 10^{6}$ cells $/ \mathrm{ml}$ in L-15 medium (Leibovitz medium, supplemented with $0.1 \% \mathrm{NaCl}$; BioWhittaker), and plated in 96-well plates at $50 \mu \mathrm{l}$ per well. The production of superoxide anion by leucocytes was measured by the nitroblue 
tetrazolium (NBT) method, as adapted by Muñoz et al. (2000). Briefly, cells were incubated with $50 \mu \mathrm{l}$ of NBT solution $(2 \mathrm{mg} / \mathrm{ml}$, Sigma) or with $50 \mu \mathrm{l}$ of NBT solution plus phorbol myristate acetate (PMA, $2 \mu \mathrm{g} / \mathrm{ml}$, Sigma), for $1 \mathrm{~h}$ at $22-24{ }^{\circ} \mathrm{C}$ in a humid chamber. Three replicate wells per fish were run and the reaction was stopped by fixing the cells in methanol. After washing twice with $70 \%$ methanol, the wells were air-dried and the resulting insoluble formazan was dissolved by adding $120 \mu \mathrm{l} 2 \mathrm{M} \mathrm{KOH}$ and $140 \mu \mathrm{l}$ dimethyl sulphoxide (Sigma). The absorbance was determined at $620 \mathrm{~nm}$.

\subsubsection{Statistics}

One-way analysis of variance (ANOVA) followed by Student-Newman-Keuls test or by Dunn's method was used to compare means of the four different groups. The significance level was set at $P<0.05$. Pearson correlation coefficients between the different variables and the percentage of plant content in diets were calculated in order to measure the strength of a linear association. All the statistical analyses were performed using Sigma Stat software (SPSS Inc., IL).

\section{Results}

\subsection{Growth performance}

Data on growth performance and liver parameters of fish fed with the four different diets are shown in Table 2. At the end of the trial, specific growth rates (SGR) were reduced only by 2.4 $\%$ and $4.2 \%$ in PP50 and PP75 groups, and their feed efficiency (FE) was significantly improved in comparison to fish fed the FM diet. At the highest replacement level (100\%), SGR was highly reduced (21.6\%), and FE was not changed respect to FM-fed fish. In all experimental groups, liver weight decreased with the decrease of weight gain and no significant changes in the heptosomatic index (HSI) were found. However, a progressive and significant increase of liver-lipid deposition was found with PP supply.

\subsection{Oxidative stress and plasma metabolites}

Plasma glucose, cholesterol and protein values are also shown in Table 2. Plasma glucose concentrations did not differ among fish fed the four diets. Cholesterol levels were significantly lower in fish fed the three plant-protein diets, with a strong linear negative correlation between both variables $(r=-0.988, P<0.05)$. Plasma protein content was significantly reduced in fish fed PP75 and PP100 diets, and a linear negative correlation was also detected between protein concentration and PP supply $\quad(r=-0.976, P<0.05)$.

Blood GSSG content decreased with the increase of dietary PP content $\quad(r=-0.53, P<$ 0.01 ) and it was significantly lower in fish fed PP100 diet (Table 3). Although the blood GSH/GSSG ratio was also correlated with the amount of PP in diets $(r=0.47, P<0.05)$, there were no significant differences among groups. Fish fed with the four diets showed no differences in hepatic GSH levels, whereas muscular GSH content was significantly higher in PP75-fed fish than in the other groups. The content of GSSG in liver was significantly lower in fish fed with the three PP diets than in those fed the FM diet, and it was negatively correlated with the percentage of plant substitution $(r=-0.59, P<0.001)$. This decrease in the hepatic GSSG content significantly increased the GSH/GSSG ratio in fish fed with plant-containing diets, and the resulting hepatic glutathione redox status was positively correlated with FM replacement $(r=0.52, P<0.01)$. There were no significant changes neither in glutathione redox status in muscle nor in hepatic GSSP levels among groups (Table 3 ).

Hepatic GR activity was significantly increased in PP100-fed fish (Table 3), whereas GR activity in muscle was significantly higher in fish fed PP100 and PP75 diets. In both tissues, GR activity was strongly associated with the percentage of plant content in diets $(r=0.62$ and 0.69 , respectively, $P<0.001)$. In addition, $\gamma \mathrm{GT}$ activity in the liver was significantly higher in PP100- 
fed fish, and a correlation between hepatic $\gamma$ GT activity and the percentage of plant content was found $(r=0.48, P<0.05) . \gamma G T$ activity in the muscle was significantly higher in fish fed PP75 diet and the lowest value was found in FM-fed fish, showing a similar pattern to muscular GSH levels.

\subsection{Histological study}

The liver structure was very similar in FM, PP50 and PP75 fish (Fig. 1A), but it showed a marked lipid accumulation in PP100-fed fish, which in some cases led to steatosis (Fig. 1B), with some aggregates of macrophages surrounding pancreatic acini. In all the fish, the villous tips and the brush border appear normal and intact, without sloughing of the mucosa into the gut lumen (Fig. 1C). Nevertheless, in fish fed the three PP diets there was an increase in the number of fat vacuoles within the enterocytes, and supranuclear deposition of protein droplets, which was most obvious in PP100-fed fish (Fig. 1D, E). However, such accumulation did not produce damage to the architecture of the gut epithelium, with no apparent signs of necrosis or cellular degeneration. In all the PP-fed fish, the architecture of the submucosa was dilated and/or hypertrophied, with connective tissue forming loose layers (Fig. 1D, E), frequently with cell infiltration (eosinophilic granular cells, mainly) (Fig. 1F), which was more obvious in PP100fed fish.

\subsection{Immunological indicators}

Data on plasma lysozyme and complement activity are shown in Figure 2. Lysozyme levels were not altered by dietary treatment. By contrast, $\mathrm{ACH}_{50}$ was increased in PP50 fed fish, and significantly decreased in PP75 and PP100-fed fish. MPO content in head kidney leucocytes remained almost unaltered in the four groups (Fig. 3A). However, MPO values in plasma increased progressively with the degree of FM replacement, being significantly higher in PP100fed fish (Fig. 3B). Concerning the cellular immune effectors, the respiratory burst activity of head kidney leucocytes after PMA stimulation was significantly higher in PP75-fed fish than in FM-fed fish, and no significant changes were found among the other experimental groups (Fig. 4).

\section{Discussion}

In the last years, a significant amount of research has been conducted on the replacement of FM by different PP. The suitability of this replacement in terms of growth performance has resulted to be highly variable among fish species and experimental conditions. Thus, specific trials have to be performed for each species. In European sea bass (Kaushik et al., 2004) and gilthead sea bream (Pereira and Oliva-Teles, 2003; Gómez-Requeni et al., 2004), recent shortterm studies have shown that at least the $60-75 \%$ of FM can be replaced by mixtures of PP without compromising growth performance. In the present study, the effects of FM replacement were studied not only on growth performance, but also on the antioxidant and non-specific immune status. In this scenario, a high level of FM replacement (50-75\%) produced a slight reduction of growth rates, but a marked decrease of feed intake and weight gain was registered with the total replacement. Moreover, when PP75 and PP100 diets were used through all the productive cycle (12 months up to market size), some kind of compensatory growth was found in finishing fish when they were fed with the PP75 diet. However, this condition was not found in fish fed the PP100 diet, and their reduced growth performance was even exacerbated over the course of time (unpublished results).

In the present work, the histologic study also revealed a marked dilation of the gut submucosa and liver steatosis only in PP100-fed fish. The lipid accumulation in enterocytes did not lead to desquamation and degeneration of the epithelium, as in previous studies in gilthead sea bream fed different lipid sources (Caballero et al., 2003) or a commercial diet to visual satiety (SitjàBobadilla et al., 2003). The infiltration of granular eosinophilic cells in the gut submucosa found in the current study is similar to that induced by soybean in Atlantic salmon, but other features 
of the typical enteritis (Baeverfjord and Krogdahl, 1996) were not observed. In Atlantic salmon also, soybean meal produced a decrease in mucosal enzymes, which were coincidental with an impaired feed conversion (Krogdahl et al., 2003). In our case, however, FE was enhanced or remained unaltered in fish fed with PP diets, which would reflect the use of different mixtures of PP and/or changes in fish species susceptibility to PP supply.

The possible adverse effects of dietary manipulations on the immune response of fish have also been studied (Waagbø, 1994; Fletcher, 1997; Kiron et al., 2004), but most of the research is focused on salmonids. The suppression of the non-specific immune capacity by high concentrations of dietary soybean proteins has been reported in rainbow trout (Burrells et al., 1999). However, other reports using soybean in rainbow trout (Rumsey et al., 1994) or alginate in Atlantic salmon (Gabrielsen and Austreng, 1998) have shown increased values of different non-specific immune mechanisms, which have been interpreted as inflammatory/hypersensitivity or immunostimulating effects. In gilthead sea bream, several authors have also studied the effect of different dietary and feeding regime manipulations on the immune or the anti-oxidant status, but none has addressed the possible effects of FM replacement by PP on both types of variables.

In the current work, we have focused on several indicators of the cellular and humoral innate immunity, which has been shown to be the first line of defence of fish before a specific immune response is mounted (Fletcher, 1982; Dalmo, 1997). In this regard, it must be noted that leucocyte intracellular killing activity was increased, as indicated by both the higher oxidative radical production (with a peak at PP75 diet) and the higher MPO content in plasma (with a peak at PP100). These two indicators were also enhanced in rainbow trout fed with soybean protein (Rumsey et al., 1994). In previous gilthead sea bream studies, the respiratory burst activity was significantly enhanced by a different dietary surpluses (Mulero et al., 1998; Castro et al., 1999; Ortuño et al., 1999, 2001, 2002; Cuesta et al., 2002; Rodríguez et al., 2003). On the contrary, leucocyte and serum MPO followed variable changes depending on the dietary manipulation, the dose and the timing (Cuesta et al., 2002, Ortuño et al., 2002, Rodríguez et al., 2003). In our work, MPO values were significantly enhanced in plasma of fish fed PP100 diet, but not in head kidney leucocytes. These higher plasma MPO levels could be due to a higher number of circulating leucocytes (granulocytes, mainly), which agrees with the infiltration of the intestinal submucosa with eosinophilic granular cells. However, this increase could have been masked in the head kidney leucocyte MPO assay, as the number of cells per well was equally adjusted for all the groups.

Other health indicators had different variations: plasma lysozyme did not vary significantly among groups, but plasma complement was markedly enhanced in PP50 fish, and reduced in fish fed PP75 and PP100 diets. In trout, equivalent diets also produced a significant decrease in $\mathrm{ACH}_{50}$ in PP100 fish (unpublished data). The increase in PP50 fish could be explained by a stimulation of complement production, which seems to be completely overwhelmed with higher PP inclusion levels. In mammals, it is well established that hepatocytes are the main source of the C3 component, and it has recently been shown that this is also the case for some fish (Abelseth et al., 2003). Thus, the progressive fat degeneration of liver (steatosis) with the PP inclusion could have produced a decrease in complement production, which is in agreement with the observed decrease of total plasma protein levels. In addition, some of the plant components (hydroxyl or amine groups of carbohydrates or proteins) could have produced a massive consumption of complement through the activation of the alternative pathway. Some authors have found no effect in haemolytic activities after FM replacement by alginates (Gabrielsen and Austreng, 1998), but complement levels have been reported to be increased in gilthead sea bream after different dietary treatments (Mulero et al., 1998; Montero et al., 1999; Ortuño et al., 1999, 2000, 2001). On the contrary, feeding with a $60 \%$ soybean oil for 204 days (Montero et al., 2003) produced a significant decrease in the haemolytic activity.

PP inclusion in gilthead sea bream diet also had effects on several of the studied metabolic and antioxidant factors, which could be considered beneficial. Most of these effects have also been found in mammals and have been associated to the presence of various classes of phenolic compounds, composed principally by ferulic acid and flavonoids, which have potent antioxidant activities associated with beneficial health effects (Adom and Liu, 2002; Bub et al., 2003). In addition, flavonoids include antiinflammatory, antiallergic, antiviral, and anticarcenogenic properties (Nijveldt et al., 2001).

The observed marked hypocholesterolemic effect agrees with the results obtained in a shorter trial in gilthead sea bream using the same diets (Gómez-Requeni et al., 2004), and also with data from other teleosts using different PP (Kaushik et al., 1995, 2004; Regost et al., 1999). 
Both in mammals and humans, different plant constituents have been reported to lower plasma cholesterol levels (Wester, 2000). Although cholesterol metabolism in mammals and fish could differ, the fish hypocholesterolemia in response to dietary PP supply could be due either to an increased excretion of bile salts, to an inhibition of cholesterol intestinal absorption, or just to the withdrawal of FM rather than to the direct effects of PP (Kaushik et al., 2004). The decrease of liver and muscle taurine levels found by Gómez-Requeni et al. (2004) would reinforce the first possibility. In any case, the significance of hypocholesterolemia in fish should be studied in depth.

From our results it appears also conclusive that PP replacement enhances the glutathione metabolism and therefore the antioxidant defences. In liver and blood, this was evident by the increase of the GSH/GSSG ratio in a dose-dependent manner with PP increment. This ratio is considered an index of the cellular redox status and a biomarker of oxidative damage. This enhanced ratio could be due to the different enzymatic reactions involved in the glutathione balance: GSH synthesis, GSH oxidation, GHS conjugation, cleavage of GHS-conjugates and GSSG reduction by GR (Meister and Anderson, 1983). The obtained data seem to indicate that the increased activity of GR could be responsible for the decrease of blood and liver GSSG levels. In addition, as glutathione levels in muscle depend largely on GSH capture from plasma by $\gamma$ GT (Griffith and Meister, 1979), PP75-fed fish presented the highest GSH levels in muscle because they had the highest muscular $\gamma \mathrm{GT}$ levels.

This higher antioxidant activity could be due to some of the plant constituents. Appelt and Reicks (1999) found higher antioxidant activities in rats fed the high isoflavone diet compared to those fed the casein diet, and Guo et al. (2002) demonstrated in vitro a higher antioxidant activity for the main flavonoids present in soy. However, the content of flavonoids in the plant mixture used in the current work is most probably low as no soybean meal was used in its formulation. Thus, other plant constituents, such as phenolic compounds (Dragsted, 2003), could have been involved, or just the lack of FM could have invoked the achieved results. In fish, the information regarding the relationship between fish nutrition and the antioxidant status is limited. Mourente et al. (2002) showed that in gilthead sea bream, dietary oxidised oils affected the activities of liver antioxidant defence enzymes, but these effects were partially restored by vitamin E. Pascual et al. (2003) also found significant increases in SOD, GR, and gluthathione peroxidase activity in gilthead sea bream in paralell to food restriction. In rainbow trout, the total hepatic glutathione, when calculated based on the total body weight, was appreciably higher in fish fed a high protein diet in comparison to those fed a low protein diet (Yokoyama and Nakazoe, 1991).

Thus, the effects are complex. On the one hand, plant-containing diets increased muscular $\mathrm{GSH}$, the hepatic glutathione redox status, and antioxidant enzyme activities as well as plasma MPO content and respiratory burst activity. This enhanced status could be useful to combat the oxidation of PUFA (Bell and Cowey, 1985), the nitrosative stress (Saeij et al., 2003,) the oxidative stress generated by food deprivation (Pascual et al., 2003), infections (Belló et al., 2000), solar UV radiation in cage farms (Zagarese and Williamson, 2001) and chemical contaminants (Peña-Llopis et al., 2003b), as well as to increase resistance to infections. In fact, other authors have found increased resistance to bacterial infections in association to increased phagocyte activity in gilthead sea bream (Mulero et al., 1998), and this increment is generally considered as an indicator of immunostimulation (Secombes et al., 1994). Nevertheless, this overactivation of leucocytes could invoke a subsequent peroxidative damage produced by the release of excessive reactive oxygen species, as shown by some authors (Ahmad et al., 2004), but, in our case, this production seems to have been counteracted by the increased activity of antioxidant enzymes. On the other hand, the lower complement levels found in our study are most probably negative for the fish. In gilthead sea bream, low complement levels, together with the depletion of other non-specific factors have been associated with winter disease syndrome and higher susceptibility to diseases (Tort et al., 1998).

Taking into account all the different aspects studied in the present study, we can conclude that total FM replacement is not feasible due to the marked impairment of growth performance. In any case, further studies (including the study of specific immune indicators and challenges with pathogens) are needed in order to assess whether this overall immunostimulated status of PP50 fish can improve resistance to diseases, and whether PP75 fish are in fact immunosupressed due to the lower complement activity. 


\section{Acknowledgements}

This study was founded by the European Union through the research project Q5RS-200030068: "Perspectives of Plant Protein Use in Aquaculture" (PEPPA). We are grateful to J. Monfort for the histological processing and to M.C. Fabregat for the care and maintenance of fish.

\section{References}

Abelseth, T.K., Stensvag, K., Espelid, S., Nygaard, R., Ellingsen, T., Bogwald, J., Dalmo, R.A. 2003. The spotted wolf fish (Anarhichas minor Olafsen) complement component C3: isolation, characterisation and tissue distribution. Fish \& Shellfish Immunol. 15, 13-27.

Adom, K.K., Liu, R.H. 2002. Antioxidant activity of grains. J. Agr. Food. Chem. 50, 6182-6187.

Ahmad, I., Pacheco, M., Santos, M.A. 2004. Enzymatic and nonenzymatic antioxidants as an adaptation to phagocyte-induced damage in Anguilla anguilla L. following in situ harbor water exposure. Ecotox. Environ. Safe. 57, 290-302.

Anderson, M.E. 1985. Determination of glutathione and glutathione disulfide in biological samples. In: Meister, A., (Ed.), Methods in Enzymology. Academic Press, London, pp. 548-555.

Appelt, L.C., Reicks, M.M. 1999. Soy induces phase II enzymes but does not inhibit dimethylbenz[a]anthracene-induced carcinogenesis in female rats. J. Nutr. 129, 1820-1826.

Baeverfjord, G., Krogdahl, A. 1996. Development and regression of soybean meal induced enteritis in Atlantic salmon, Salmo salar L., distal intestine: a comparison with the intestines of fasted fish. J. Fish Dis. 19, 375-387.

Baker, M.A., Cerniglia, G.J., Zaman, A. 1990. Microtiter plate assay for the measurement of glutathione and glutathione disulfide in large numbers of biological samples. Anal. Biochem. 190, 360-365.

Bell, J.G., Cowey, C.B. 1985. Roles of vitamin E and selenium in the prevention of pathologies related to fatty acid oxidation in salmonids. In: Cowey, C.B., Mackie, A.M., Bell, J.G. (Eds.), Nutrition and feeding in fish. Academic Press, London, pp. 333-347.

Belló, A.R., Fortes, E., Belló-Klein, A., Belló, A.A., Llesuy, S.F., Robaldo, R.B., Bianchini, A. 2000. Lipid peroxidation induced by Clinostomum detruncatum in muscle of the freshwater fish Rhamdia quelen. Dis. Aquat. Org. 42, 233-236.

Bub, A., Watzl, B., Blockhaus, M., Briviba, K., Liegibel, U., Müller, H., Pool-Zobel, B.L., Rechkemmer, G. 2003. Fruit juice consumption modulates antioxidative status, immune status and DNA damage. J. Nutr. Biochem. 14, 90-98.

Burrells, C., Williams, P.D., Southgate, P.J., Crampton, V.O. 1999. Immunological, physiological and pathological responses of rainbow trout (Oncorhynchus mykiss) to increasing dietary concentrations of soybean proteins. Vet. Immunol. Immunopathol. 72, 277-288.

Caballero, M.J., Izquierdo, M.S., Kjorsvik, E., Montero, D., Socorro, J., Fernández, J.A., Rosenlund, G. 2003. Morphological aspects of intestinal cells from gilthead sea bream (Sparus aurata) fed diets containing different lipid sources. Aquaculture 225, 325-340. 
Calduch-Giner, J.A., Sitjà-Bobadilla, A., Alvarez-Pellitero, P., Pérez-Sánchez, J. 1997. Growth hormone as an in vitro phagocyte-activating factor in the gilthead sea bream (Sparus aurata). Cell. Tissue Res. 287, 535-540.

Castro, R., Couso, N., Obach, A., Lamas, J. 1999. Effect of different $\beta$-glucans on the respiratory burst of turbot (Psetta maxima) and gilthead seabream (Sparus aurata) phagocytes. Fish \& Shellfish Immunol. 9, 529-541.

Cribb, A.E., Leeder, J.S., Spielberg, S.P. 1989. Use of a microplate reader in an assay of glutathione reductase using 5,5'-dithiobis(2-nitrobenzoic acid). Anal. Biochem. 183, 195-196.

Cuesta, A., Ortuño, J., Esteban, M.A., Rodríguez, M.A., Meseguer, J. 2002. Changes in some innate defence parameters of seabream (Sparus aurata L.) induced by retinol acetate. Fish \& Shellfish Immunol. 13, 279-291.

Dalmo, R.A., Ingebrigtsen, K., Bogwald, J. 1997 Non-specific defence mechansms in fish, with particular reference to the reticuloendothelial system (RES). Journal of Fish Diseases 20, 241273.

Dragsted L.O. 2003. Antioxidant actions of polyphenols in humans. Int. J. Vit. Nutr. Res. 73, 112-119.

Ellis, A.E. 1990. Lysozyme assays In: Stolen, J.S., Fletcher, T.C., Anderson, D.P., Roberson, B.S., Van Muiswinkel, W.B. (Eds.), Techniques in fish immunology. SOS Publications, Fair Haven, NJ, pp. 101-103.

Fletcher, T.C. 1982. Non-specific defence mechanisms of fish. Dev. Comp. Immunol.S2, 123132.

Fletcher, T.C. 1997. Dietary effects on stress and health. In: Iwama, G.K., Pickering, A.D., Schreck, C.B. (Eds.), Fish stress and health in aquaculture. Cambridge University Press, Cambridge, pp. 223-244.

Gabrielsen, B.O., Austreng, E. 1998. Growth, product quality and immune status of Atlantic salmon, Salmo salar L., fed wet feed with alginate. Aquacult. Res. 29, 397-401.

Gómez-Requeni, P., Mingarro, M., Calduch-Giner, J.A., Médale, F., Martin, S.A.M., Houlihan, D.F., Kaushik, S., Pérez-Sánchez, J. 2004. Protein growth performance, amino acid utilisation and somatotropic axis responsiveness to fish meal replacement by plant protein sources in gilthead sea bream (Sparus aurata). Aquaculture 232, 493-510.

Griffith, O.W., Meister, A. 1979. Glutathione: interorgan translocation, turnover, and metabolism. Proc. Natl. Acad. Sci. USA 76, 5606-5610.

Guo, Q., Rimbach, G., Moini, H., Weber, S., Packer, L. 2002. ESR and cell culture studies on free radical-scavenging and antioxidant activities of isoflavonoids. Toxicology 179, 171-180.

Kaushik, S.J., Cravedi, J.P., Lalles, J.P., Sumpter, J., Fauconneau, B., Laroche, M. 1995. Partial or total replacement of fish meal by soybean protein on growth, protein utilization, potential estrogenic or antigenic effects, cholesterolemia and flesh quality in rainbow trout, Oncorhynchus mykiss. Aquaculture 133, 257-274.

Kaushik, S.J., Covès, D., Dutto, G., Blanc, D. 2004. Almost total replacement of fish meal by plant protein sources in the diet of a marine teleost, the European seabass, Dicentrarchus labrax. Aquaculture 230, 391-404.

Kiron, V., Puangkaew, J., Ishizaka, K., Satoh, S., Watanabe, T. 2004. Antioxidant status and nonspecific immune responses in rainbow trout (Oncorhynchus mykiss) fed two levels of vitamin E along with three lipid sources. Aquaculture 234, 361-379. 
Kissil, G.W., Lupatsch, I., Higgs, D.A., Hardy, R.W. 2000. Dietary substitution of soy and rapeseed protein concentrates for fish meal, and their effects on growth and nutrient utilization in gilthead seabream Sparus aurata L. Aquacult. Res. 31, 595-601.

Krogdahl , A., Bakke-Mckellep, A.M., Baeverjord, G. 2003. Effects of graded levels of standard soybean meal on intestinal structure, mucosal enzyme activities, and pancreatic response in Atlantic salmon (Salmo salar L.). Aquacult. Nutr. 9, 361-371.

Meister, A., Anderson, M.E. 1983. Glutathione. Annu. Rev. Biochem. 52, 711-760.

Montero, D., Marrero, M., Izquierdo, M.S., Vergara, J.M., Tort, L. 1999. Effect of vitamin E and $C$ dietary supplementation on some immune parameters of gilthead seabream (Sparus aurata) juveniles subjected to crowding stress. Aquaculture 171, 269-278.

Montero, D., Kalinowski, T., Obach, A., Robaina, L., Tort, L., Caballero, M.J., Izquierdo, M.S. 2003. Vegetable lipid sources for gilthead seabream (Sparus aurata): effects on fish health. Aquaculture 225, 353-370.

Mourente, G., Díaz-Salvago, E., Bell, J.G., Tocher DR. 2002. Increased activities of hepatic antioxidant defence enzymes in juvenile gilthead sea bream (Sparus aurata L.) fed dietary oxidised oil: attenuation by dietary vitamin E. Aquaculture 214, 343-361.

Mulero, V., Esteban, M.A., Muñoz, J., Meseguer, J. 1998. Dietary intake of levamisole enhances the immune response and disease resistance of the marine teleost gilthead seabream (Sparus aurata L.). Fish \& Shellfish Immunol. 8, 49-62.

Muñoz, P., Calduch-Giner, J.A., Sitjà-Bobadilla, A., Alvarez-Pellitero, P., Pérez-Sánchez, J. 1998. Modulation of the respiratory burst activity of Mediterranean sea bass (Dicentrarchus labrax L.) phagocytes by growth hormone and parasitic status. Fish \& Shellfish Immunol. 8, 2536.

Muñoz, P,, Sitjà-Bobadilla, A., Alvarez-Pellitero, P. 2000. Cellular and humoral immune response of European sea bass (Dicentrarchus labrax L.) (Teleostei: Serranidae) immunized with Sphaerospora dicentrarchi (Myxosporea: Bivalvulida). Parasitology 120, 465-477.

National Research Council (NRC). 1993, Nutrient Requirements of Fish. Washington, DC: National Academy Press, 124 pp.

Nijveldt, R.J., Van Nood, E., Van Hoorn, D.E., Boelens, P.G., Van Norren, K., Van Leeuwen, P.A. 2001. Flavonoids: a review of probable mechanisms of action and potential applications. Am. J. Clin. Nutr. 74, 418-425.

Ortuño, J, Esteban, M.A., Meseguer, J. 1999. Effect of high dietary intake of vitamin C on nonspecific immune response of gilthead sea bream (Sparus aurata L.). Fish \& Shellfish Immunol. 9, 429-443.

Ortuño, J., Esteban, M.A., Meseguer, J. 2000. High dietary intake of alpha-tocopherol acetate enhances the non-specific immune response of gilthead seabream (Sparus aurata L.). Fish \& Shellfish Immunol. 10, 293-307.

Ortuño, J., Cuesta, A., Esteban, M.A., Meseguer, J. 2001. Effect of oral administration of high vitamin $C$ and $E$ dosages on the gilthead seabream (Sparus aurata L.) innate immune system. Vet. Immunol. Immunopathol. 79, 167-180.

Ortuño, J., Cuesta, A., Rodríguez, A., Esteban, M.A., Meseguer, J. 2002. Oral administration of yeast, Saccharomyces cerevisiae, enhances the cellular innate immune response of gilthead seabream (Sparus aurata L.). Vet. Immunol. Immunopathol. 85, 41-50. 
Pascual, P., Pedrajas, J.R., Toribio, F., López-Barea, J., Peinado, J. 2003. Effect of food deprivation on oxidative stress biomarkers in fish (Sparus aurata). Chem-Biol. Interactions 145, 191-199.

Peña-Llopis, S., Peña, J.B., Sancho, E., Fernandez-Vega, C., Ferrando, M.D. 2001. Glutathione-dependent resistance of the European eel Anguilla anguilla to the herbicide molinate. Chemosphere 45, 671-681.

Peña-Llopis, S., Ferrando, M.D., Peña, J.B. 2003a. Fish tolerance to organophosphate-induced oxidative stress is dependent on the glutathione metabolism and enhanced by $\mathrm{N}$-acetylcysteine. Aquat. Toxicol. 65, 337-360.

Peña-Llopis, S., Ferrando, M.D., Peña, J.B. 2003b. Increased recovery of brain acetylcholinesterase activity in dichlorvos-intoxicated European eels (Anguilla anguilla) by bath treatment with $\mathrm{N}$-acetylcysteine. Dis. Aquat. Org. 2003b 55, 237-245.

Pereira, T.G., Oliva-Teles, A. 2002. Preliminary evaluation of pea seed meal in diets for gilthead sea bream (Sparus aurata) juveniles. Aquacult. Res. 33, 1183-1189.

Pereira, T.G., Oliva-Teles, A. 2003. Evaluation of corn gluten meal as a protein source in diets for gilthead sea bream (Sparus aurata L.) juveniles. Aquacult. Res. 34, 1111-1117.

Quade, M.J., Roth, J.A. 1997. A rapid, direct assay to measure degranulation of bovine neutrophil primary granules. Vet. Immunol. Immunopathol. 58, 239-248.

Regost, C.J., Arzel, J., Kaushik, S.J. 1999. Partial or total replacement of fish meal by corn gluten meal in diet for turbot (Psetta maxima). Aquaculture 180, 99-117.

Riddles, P.W., Blakeley, R.L., Zerner, B. 1979. Ellman's reagent: 5,5'-dithiobis(2-nitrobenzoic acid) - a reexamination. Anal. Biochem. 94, 75-81.

Robaina, L., Izquierdo, M.S., Moyano, F.J., Socorro, J., Vergara, J.M., Montero, D., FernándezPalacios, H. 1995. Soybean and lupin seed meals as protein sources in diets for gilthead seabream (Sparus aurata): nutritional and histological implications. Aquaculture 130, 219-233.

Rodríguez, A., Cuesta, A., Ortuno, J., Esteban, M.A., Meseguer, J. 2003. Immunostimulant properties of a cell wall-modified whole Saccharomyces cerevisiae strain administered by diet to seabream (Sparus aurata L.). Vet. Immunol. Immunopathol. 96, 183-192

Rossi, R., Cardaioli, E., Scaloni, A., Amiconi, G., Di Simplicio, P. 1995. Thiol groups in proteins as endogenous reductants to determine glutathione-protein mixed disulphides in biological systems. Biochim. Biophys. Acta. 1243, 230-238.

Rumsey, G.L., Siwicki, A.K., Anderson, D.P., Bowser, P.R. 1994. Effect of soybean protein on serological response, nonspecific defense-mechanisms, growth, and protein-utilization in rainbow-trout. Vet. Immunol. Immunopathol. 41, 323-339.

Saeij, J.P.J., Van Muisvinkel, W.B., Van de Meent, M., Anaral, C., Wiegertjes, G.F. 2003. Different capacities of carp leucocytes to encounter nitric oxide-mediated stress: a role for the intracellular reduced gluthatione pool. Dev. Comp. Immunol. 27, 555-568.

Secombes, C.J. 1994. Enhancement of fish phagocyte activity. Fish \& Shellfish Immunol. 4, 421-436.

Silber, P.M., Gandolfi, A.J., Brendel, K. 1986. Adaptation of a gamma-glutamyl transpeptidase assay to microtiter plates. Anal. Biochem. 158, 68-71. 
Sitjà-Bobadilla, A., Mingarro, M., Pujalte, M.J., Garay, E., Alvarez-Pellitero, P., Pérez-Sánchez, J. 2003. Immunological and pathological status of gilthead sea bream (Sparus aurata L.) under different long-term feeding regimes. Aquaculture 220, 707-724.

Smith, I.K., Vierheller, T.L., Thorne, C.A. 1988. Assay of glutathione reductase in crude tissue homogenates using 5,5'-dithiobis(2-nitrobenzoic acid). Anal. Biochem. 175, 408-413.

Sunyer, J.O., Tort, L. 1995. Natural hemolitic and bacterial activities of seabream Sparus aurata serum are affected by the alternative complement pathway. Vet. Immunol. Immunopathol. 45, 333-345.

Tort, L., Padrós, F., Rotllant, J., Crespo, S. 1998. Winter syndrome in the gilthead sea bream Sparus aurata. Immunological and histopathological features. Fish Shellfish \& Immunol. 8, 3747.

Vielma, J., Koskela, J., Ruohonen, K., Jokinen, I., Kettunen, J. 2003. Optimal diet composition for European whitefish (Coregonus lavaretus): carbohydrate stress and immune parameter responses. Aquaculture, 225:3-16.

Waagbø, R. 1994. The impact of nutritional factors on the immune system in Atlantic salmon, Salmo salar L.: a review. Aquacult. Fish. Manag. 25, 175-197.

Wester I. 2000. Cholesterol-lowering effect of plant sterols. Eur. J. Lipid Sci. Tech. 102, 37-44.

Yokoyama, M., Nakazoe, J. 1991. Effects of dietary-protein levels on free amino-acid and glutathione contents in the tissues of rainbow-trout. Comp. Biochem. Physiol. 99A, 203-206.

Zagarese, H.E., Williamson, C.E. 2001. The implications of solar UV radiation exposure for fish and fisheries. Fish Fisheries 2, 250-260.

\section{Figure legends}

Fig. 1. Histological sections of gilthead sea bream fed with FM $(A, C)$ or PP100 (B, D, E) diets. Notice the difference between normal (A) and steatosic (B) liver. Normal distal intestine (C) differs from intestines with supranuclear deposition of protein droplets (arrow, D), lipidic vacuolisation (arrow, E), and dilated/hypertrophied submucosa (* D, E), with eosinophilic infiltration (F). Stainings: toluidine blue (A-E), $H$ \& E (F). Bars $=20 \mu \mathrm{m}$.

Fig. 2. Plasma lysozyme (A) and complement alternative pathway activity $\left(\mathrm{ACH}_{50}\right)(B)$ in the four experimental groups. Each bar represents mean \pm S.E.M. Different letters stand for statistically significant differences at $P<0.05$.

Fig. 3. Myeloperoxidase activity in head kidney leucocytes (A) and plasma (B) in gilthead sea bream fed with the four experimental diets. Each bar represents mean \pm S.E.M. Different letters stand for statistically significant differences at $P<0.05$.

Fig. 4. Respiratory burst activity of head kidney leucocytes of gilthead sea bream fed with the four experimental diets. Each bar represents mean \pm S.E.M. Different letters stand for statistically significant differences at $P<0.05$ 


\section{Table 1}

Ingredients and chemical composition of experimental diets.

\begin{tabular}{|c|c|c|c|c|}
\hline \multirow[t]{2}{*}{ Ingredient $(\mathrm{g} / \mathrm{kg})$} & \multicolumn{4}{|c|}{ Diet } \\
\hline & FM & PP50 & PP75 & PP100 \\
\hline Fish meal, LT (CP 70\%) & 703.7 & 352 & 176 & 0 \\
\hline Corn gluten meal & 0 & 120 & 180 & 250 \\
\hline Wheat gluten & 0 & 120 & 180 & 250 \\
\hline Extruded peas (Aquatex) & 0 & 60 & 90 & 120 \\
\hline Rapeseed meal (Primor 00) & 0 & 30 & 67.2 & 27.3 \\
\hline Sweet white lupin meal & 0 & 0 & 0 & 6.9 \\
\hline Extruded whole wheat & 142.0 & 94.9 & 30.6 & 15.5 \\
\hline Fish oil & 124.3 & 141.3 & 149.8 & 158 \\
\hline Binder (Na Alginate) & 10 & 10 & 10 & 10 \\
\hline Mineral premix ${ }^{1}$ & 10 & 10 & 10 & 10 \\
\hline Vitamin premix ${ }^{2}$ & 10 & 10 & 10 & 10 \\
\hline $\mathrm{CaHPO}_{4} .2 \mathrm{H}_{2} \mathrm{O}(18 \% \mathrm{P})$ & 0 & 6.5 & 30 & 51.1 \\
\hline IAA mix ${ }^{3}$ & 0 & 44.3 & 65.7 & 91.4 \\
\hline \multicolumn{5}{|l|}{ Analysed composition } \\
\hline Dry matter (DM, \%) & 93.7 & 94.3 & 91.9 & 90.1 \\
\hline Crude protein (\% DM) & 46.1 & 47.5 & 44.8 & 42.8 \\
\hline Crude fat (\% DM) & 16.5 & 16.6 & 17.2 & 16.8 \\
\hline Gross energy (kJ/g DM) & 20.4 & 21.3 & 21.4 & 21.7 \\
\hline $\mathrm{IAA}(\% \mathrm{DM})^{3}$ & 24.6 & 25.5 & 25.7 & 24.8 \\
\hline $\mathrm{DAA}(\% \mathrm{DM})^{4}$ & 23.2 & 21.9 & 22.6 & 23.2 \\
\hline IAA/DAA & 1.06 & 1.16 & 1.14 & 1.07 \\
\hline
\end{tabular}

${ }^{1,2}$ Mineral premix and vitamin premix according to NRC recommendations.

${ }^{3}$ Indispensable amino acids.

${ }^{4}$ Dispensable amino acids. 


\section{Table 2}

Growth performance, liver fat content and plasma levels of glucose, cholesterol and proteins in fish fed the experimental diets.

\begin{tabular}{|c|c|c|c|c|}
\hline & \multicolumn{4}{|c|}{ Diet } \\
\hline & FM & PP50 & PP75 & PP100 \\
\hline Initial body weight (g) & $16.4 \pm 0.07$ & $16.7 \pm 0.11$ & $16.5 \pm 0.19$ & $16.4 \pm 0.24$ \\
\hline Final body weight (g) & $200.5 \pm 2.3^{\mathrm{d}}$ & $190.9 \pm 1.4^{\mathrm{c}}$ & $181.4 \pm 1.3^{\mathrm{b}}$ & $123.7 \pm 1.5^{\mathrm{a}}$ \\
\hline Feed intake (g DM/fish) & $238.8 \pm 5.4^{\mathrm{d}}$ & $184.5 \pm 1.8^{\mathrm{c}}$ & $168.7 \pm 1.9^{\mathrm{b}}$ & $127.9 \pm 1.1^{\mathrm{a}}$ \\
\hline $\operatorname{SGR}(\%)^{1}$ & $1.66 \pm 0.02^{\mathrm{c}}$ & $1.62 \pm 0.01^{\mathrm{bc}}$ & $1.59 \pm 0.01^{\mathrm{b}}$ & $1.30 \pm 0.03^{\mathrm{a}}$ \\
\hline $\mathrm{FE}^{2}$ & $0.85 \pm 0.01^{\mathrm{a}}$ & $0.95 \pm 0.03^{\mathrm{b}}$ & $0.98 \pm 0.01^{\mathrm{b}}$ & $0.84 \pm 0.04^{\mathrm{a}}$ \\
\hline Liver weight (g) & $3.08 \pm 0.23^{b}$ & $2.89 \pm 0.21^{b}$ & $2.16 \pm 0.16^{\mathrm{ab}}$ & $2.01 \pm 0.20^{\mathrm{a}}$ \\
\hline $\operatorname{HSI}(\%)^{3}$ & $1.61 \pm 0.08$ & $1.53 \pm 0.07$ & $1.35 \pm 0.07$ & $1.56 \pm 0.11$ \\
\hline Liver fat (\% wet matter) & $7.09 \pm 0.65^{\mathrm{a}}$ & $7.46 \pm 0.13^{\mathrm{a}}$ & $9.85 \pm 1.25^{\mathrm{a}}$ & $14.3 \pm 1.50^{\mathrm{b}}$ \\
\hline \multicolumn{5}{|l|}{ Plasma metabolites } \\
\hline Glucose (mg/dl) & $59.6 \pm 2.8$ & $64.8 \pm 3.9$ & $63.1 \pm 5.1$ & $62.9 \pm 3.7$ \\
\hline Cholesterol (mg/dl) & $328.4 \pm 20.1^{\mathrm{d}}$ & $243.8 \pm 11.4^{\mathrm{c}}$ & $170.2 \pm 9.6^{\mathrm{b}}$ & $94.9 \pm 6.2^{\mathrm{a}}$ \\
\hline Protein $(\mathrm{mg} / \mathrm{ml})$ & $53.7 \pm 1.4^{\mathrm{b}}$ & $48.1 \pm 2.7^{b}$ & $39.9 \pm 1.4^{\mathrm{a}}$ & $36.9 \pm 1.1^{\mathrm{a}}$ \\
\hline
\end{tabular}

Tank average values of fish weight and feed intake (means \pm S.E.M.) were used as experimental units for the statistical analysis of growth performance. Liver weight and lver lipid content (means \pm S.E.M.) were calculated from 10-12 fish.

Means in the same line not sharing a common superscript letter are significantly different $(P<0.05)$.

${ }^{1}$ Specific growth rate $=[100 \times(\ln$ final fish $w t .-\ln$ initial fish wt. $)] /$ days.

${ }^{2}$ Feed efficiency $=$ wet weight gain $/$ dry feed intake.

${ }^{3}$ Hepatosomatic index $=(100 \times$ liver wt. $) /$ fish wt. 


\section{Table 3}

Glutathione levels in blood, liver and white muscle and activities of glutathione reductase, and ?-glutamyl transferase in liver and white muscle of fish fed the four experimental diets.

\begin{tabular}{|c|c|c|c|c|c|}
\hline & & \multicolumn{4}{|c|}{ Diet } \\
\hline & & FM & PP50 & PP75 & PP100 \\
\hline \multicolumn{6}{|c|}{ Glutathione } \\
\hline \multirow[t]{3}{*}{ Blood } & $\mathrm{GSH}(\mu \mathrm{mol} / \mathrm{L})^{1}$ & $537 \pm 28$ & $466 \pm 31$ & $485 \pm 34$ & $449 \pm 31$ \\
\hline & $\mathrm{GSSG}(\mu \mathrm{mol} / \mathrm{L})^{2}$ & $67 \pm 7^{\mathrm{b}}$ & $49 \pm 6^{\mathrm{ab}}$ & $48 \pm 4^{\mathrm{ab}}$ & $44 \pm 5^{\mathrm{a}}$ \\
\hline & GSH/GSSG & $16 \pm 1.1$ & $19 \pm 1.1$ & $20 \pm 1.0$ & $21 \pm 1.8$ \\
\hline \multirow[t]{4}{*}{ Liver } & GSH (nmol/g wet wt) & $2994 \pm 247$ & $3315 \pm 222$ & $3189 \pm 227$ & $2676 \pm 240$ \\
\hline & GSSG (nmol/g wet wt) & $40 \pm 5.4^{\mathrm{b}}$ & $27 \pm 2.9^{\mathrm{a}}$ & $25 \pm 1.1^{\mathrm{a}}$ & $22 \pm 3.2^{\mathrm{a}}$ \\
\hline & GSH/GSSG & $163 \pm 22^{\mathrm{a}}$ & $254 \pm 21^{\mathrm{b}}$ & $254 \pm 19^{\mathrm{b}}$ & $256 \pm 27^{\mathrm{b}}$ \\
\hline & GSSP (nmol/mg prot) ${ }^{3}$ & $8.3 \pm 1.6$ & $6.2 \pm 0.3$ & $7.7 \pm 0.8$ & $5.3 \pm 0.8$ \\
\hline \multirow[t]{3}{*}{ Muscle } & GSH (nmol/g wet wt) & $126 \pm 6^{\mathrm{a}}$ & $154 \pm 15^{\mathrm{ab}}$ & $172 \pm 13^{b}$ & $145 \pm 9^{\mathrm{ab}}$ \\
\hline & GSSG (nmol/g wet wt) & $5.7 \pm 0.4$ & $7.1 \pm 1.3$ & $7.0 \pm 1.1$ & $7.1 \pm 1.2$ \\
\hline & GSH/GSSG & $46 \pm 4$ & $47 \pm 5$ & $58 \pm 11$ & $50 \pm 9$ \\
\hline \multicolumn{6}{|c|}{ Glutathione Reductase (GR) } \\
\hline Liver & (mU/mg protein) & $7.8 \pm 0.4^{\mathrm{a}}$ & $8.2 \pm 0.3^{\mathrm{a}}$ & $9.0 \pm 0.5^{\mathrm{a}}$ & $10.2 \pm 0.5^{\mathrm{b}}$ \\
\hline Muscle & (mU/mg protein) & $2.68 \pm 0.13^{\mathrm{a}}$ & $2.86 \pm 0.08^{\mathrm{a}}$ & $3.26 \pm 0.12^{b}$ & $3.54 \pm 0.17^{b}$ \\
\hline \multicolumn{6}{|c|}{ ?-Glutamyl Transferase (?GT) } \\
\hline Liver & (mU/mg protein) & $0.69 \pm 0.09^{\mathrm{ab}}$ & $0.51 \pm 0.06^{\mathrm{a}}$ & $0.89 \pm 0.10^{\mathrm{bc}}$ & $1.15 \pm 0.15^{\mathrm{c}}$ \\
\hline Muscle & (mU/mg protein) & $0.055 \pm 0.002^{\mathrm{a}}$ & $0.063 \pm 0.004^{\mathrm{ab}}$ & $0.072 \pm 0.004^{\mathrm{b}}$ & $0.060 \pm 0.007^{\mathrm{ab}}$ \\
\hline
\end{tabular}

Values (means \pm S.E.M.) in the same line not sharing a common superscript letter are significantly different $(P<0.05)$.

${ }^{1}$ Glutathione reduced form.

${ }^{2}$ Glutathione disulphide (oxidised form).

${ }^{3}$ Glutathione-protein mixed disulphide. 


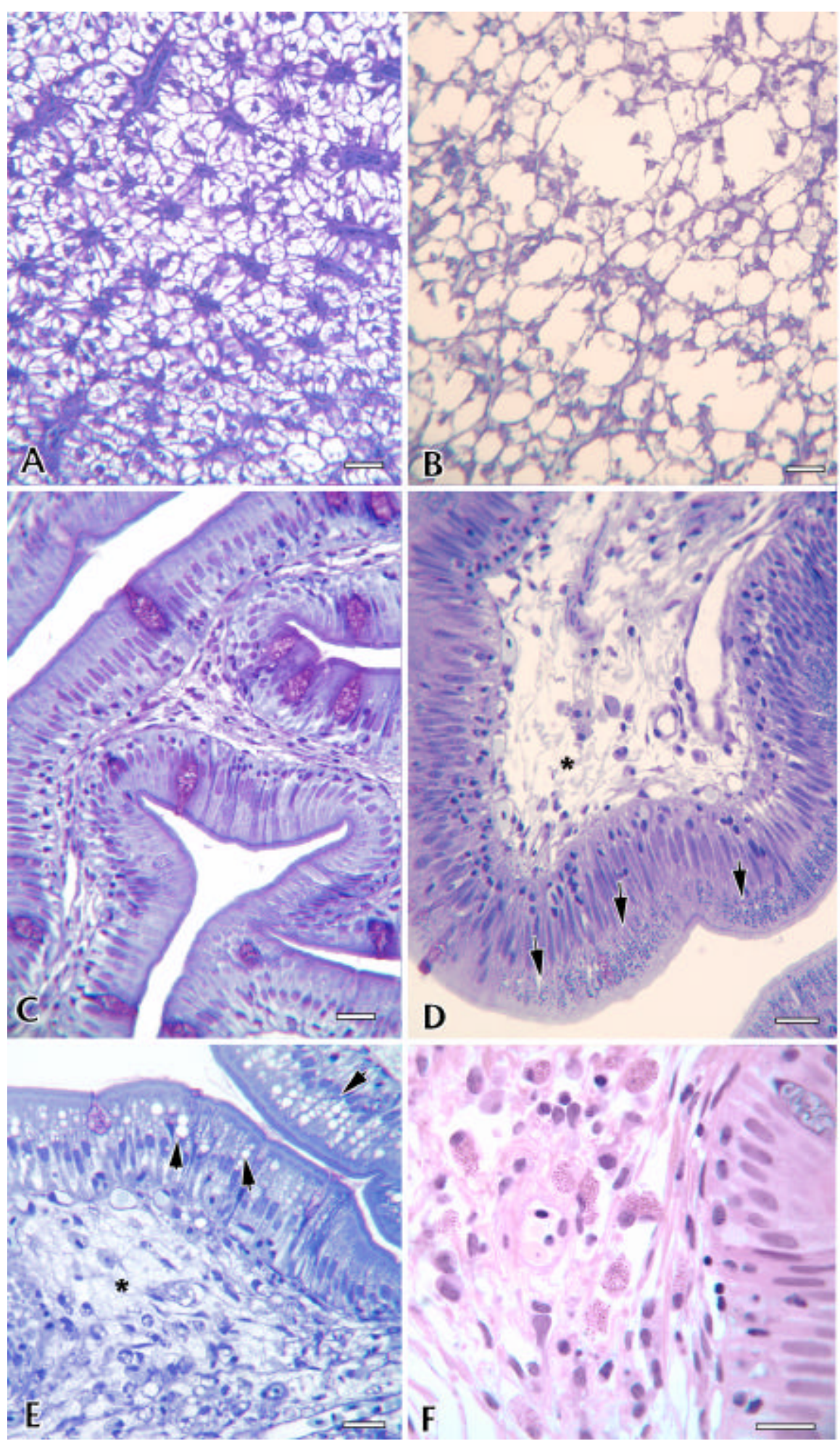

Fig.1 
Fig.2
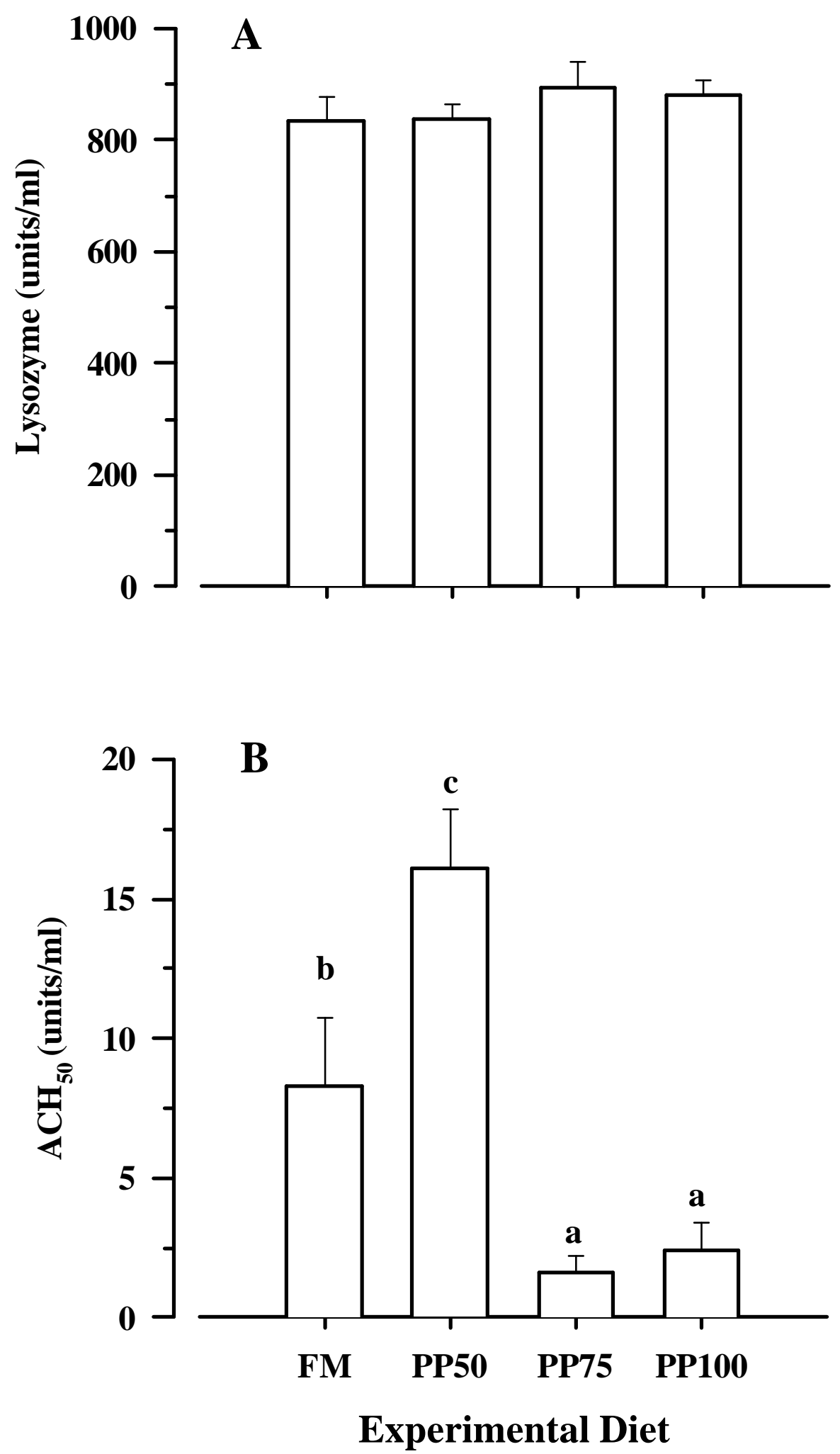
Fig. 3

MPO Activity
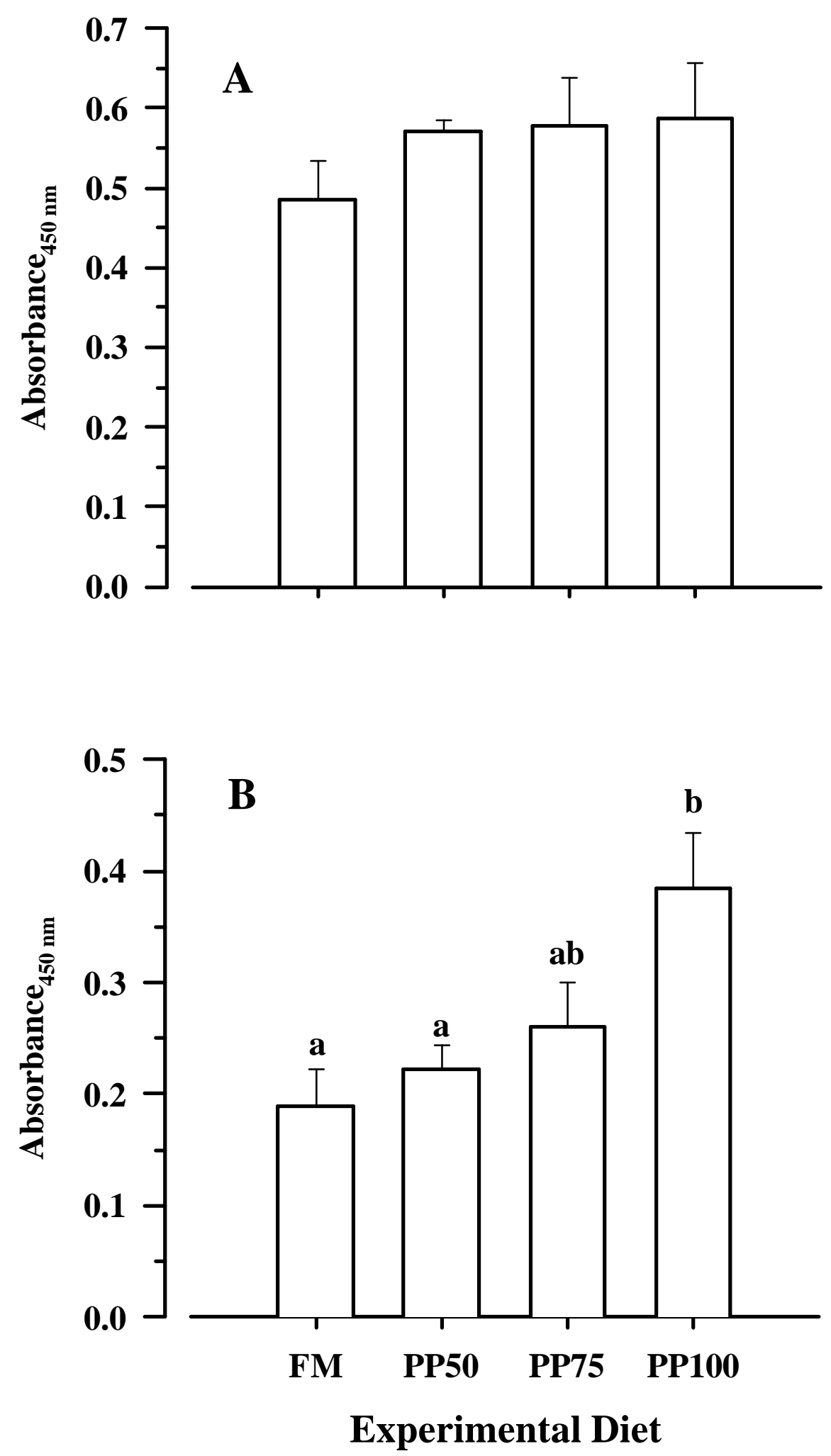
Fig.4

Respiratory Burst

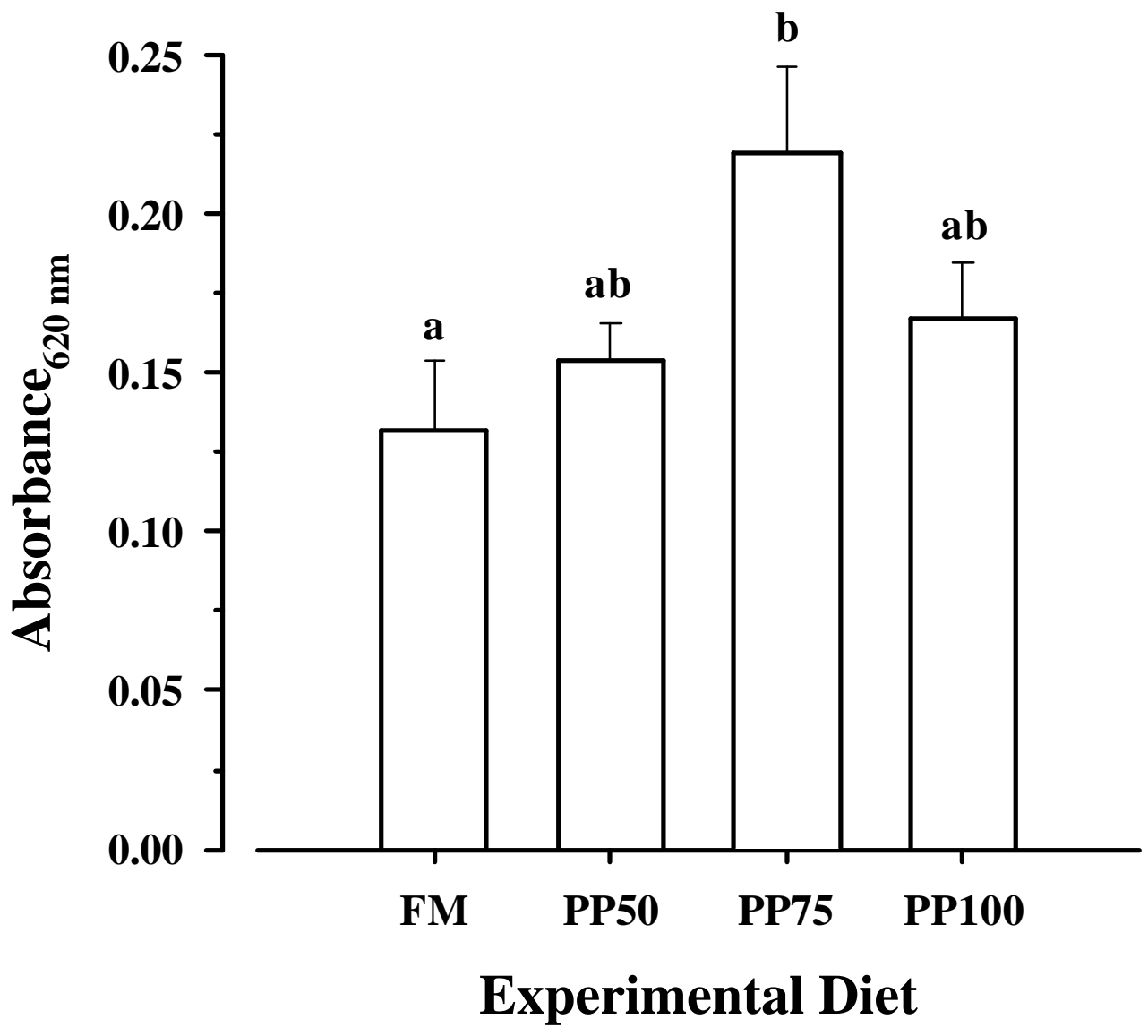

